\title{
CALVIN'S PREFACE TO CHRYSOSTOM'S HOMILIES AS A WINDOW INTO CALVIN'S OWN PRIORITIES AND PERSPECTIVES
}

\author{
PAUl A. HARTOG* \\ Faith Baptist Theological Seminary
}

\begin{abstract}
John Calvin drew from patristic authors in a selective manner. His preference for the theological perspectives of Augustine is readily evident. Nevertheless, while he resonated with the doctrine of Augustine, he touted the interpretive and homiletic labors of John Chrysostom. Even though Calvin's Institutes of the Christian Religion critiqued Chrysostom's understanding of grace and free will, the Antiochene bishop is the most frequently referenced patristic author within Calvin's commentaries. Calvin composed a preface to a projected edition of Chrysostom's homilies (Praefatio in Chrysostomi Homilias). This preface argued for the necessity of reaching the general public with secondary aids along with the scriptures, explained Calvin's esteem for Chrysostom's homilies above other patristic texts, and acknowledged the theological dissimilarities that separated his views from Chrysostom's. The Praefatio's assessments reveal Calvin's own hermeneutical, pastoral, and theological priorities. Calvin's evaluations of Chrysostom and the other fathers are a window into his own interpretive concerns, homiletical aims, and dogmatic emphases.
\end{abstract}

KEYWORDS: biblical interpretation, Calvin, Chrysostom, hermeneutics

The church fathers undoubtedly influenced John Calvin's thought (Torrance 1988: 720). Back in 1964, William Newton Todd completed a doctoral dissertation that examined Calvin's use of patristic sources. 'In general', concluded Todd, 'his knowledge of the Fathers, councils, and history of Christian antiquity was outstanding for his day' (Todd 1964: 169). Todd added, 'His learning was broad and his patristic citations for the most part were naturally and logically woven into the text and context of his writings' (Todd 1964: 169). Over the last few decades, Calvin scholarship has witnessed a renewed interest in Calvin's reception of patristic sources (Lane 1981: 191-200; Steinmetz 1990; van Oort 1997: 61; Lane 1999; Backus 2000; Backus 2009; Steinmetz 2010). These contemporary scholars have often leaned toward more nuance in their assessment of the breadth and

* PAUL A. HARTOG (PhD 2000, Loyola University Chicago) is Professor of Theology at Faith Baptist Theological Seminary. Email: hartogp@faith.edu. 
depth of Calvin's knowledge of the fathers and of his employment of their works (Backus 2000).

Calvin's usage of the fathers was 'primarily polemical' (van Oort 1997: 671, 698; cf. Lane 1981: 164). His knowledge of patristic literature reflects a fairly limited canon, focused primarily on post-Nicene authors (Backus 2000: 253, 276). Calvin's dedicatory letter to Simon Grynaeus referenced 'ancient commentators, whose godliness, learning, sanctity and age have secured them such great authority that we should not despise anything they have produced' (quoted in Steinmetz 1990: 100). In his reception of patristic sources, Calvin claimed to reflect burgeoning humanist emphases, such as the desire to separate genuine from spurious works, the intention to interpret the texts within their original historical contexts, and the willingness to consider mitigating circumstances (van Oort 1997: 673, 680, 687, 690). For example, Calvin accused Pighius of quoting Augustine out of context without consideration of real intention (van Oort 1997: 678). Nevertheless, Calvin did not always live up to these purported ideals (Backus 2000).

Calvin's reception of the fathers was selective, generally ignoring facets such as patristic spirituality, asceticism, and monasticism (Backus 2000). He demonstrated preference for specific authors and passages, based upon his personal perspectives (Backus 2000: 273). Calvin explicitly explained his tendencies in a preface to a proposed edition of John Chrysostom's homilies. The process of assessment often reveals as much about the one assessing as the one assessed. Calvin's preface not only describes Chrysostom's work, it also provides insights into Calvin's own theological and hermeneutical priorities. Calvin's assessments of Chrysostom and the other fathers within the preface are a window into his own interpretive concerns, homiletical aims, and dogmatic emphases. His values are recognized through his evaluations.

\section{Augustine and Chrysostom}

In a 1539 letter to Sadolet, Calvin declared, 'I ask you to place before your eyes the ancient form of the Church as their writings prove it to have been in the ages of Chrysostom and Basil among the Greeks, and of Cyprian, Ambrose and Augustine among the Latins' (quoted in Todd 1964: 172-173). Todd concluded that Calvin's special 'favorites' among the fathers were Augustine and Chrysostom, two authors who 'enjoyed a unique place' in his thought (Todd 1964: 173, 177; cf. Papp 2016: 423). While Chrysostom was a favored Greek father, his influence upon Calvin still lagged significantly behind the influence of the Bishop of Hippo (Warfield 1956; Smits 1958). For Calvin, Augustine was 'the patristic authority par excellence' (van Oort 1997: 682-783). He held the African bishop in 'the highest regard' (Lane 1981: 171). In his Treatise on Predestination, Calvin even declared, 'As for St. 
Augustine, he agrees so well with us in everything and everywhere, that if I had to write a confession upon this matter it would be enough for me to compose it from evidences drawn from his books' (quoted in Wendel 2002: 125). Nevertheless, on occasion Calvin did express disagreements with Augustine's theology or conceptualizations (Institutes III.3.10-12). He could even name Augustine among those "who build upon Christ, but in consequence of the weakness of the flesh, admit something that is man's or through ignorance turn aside to some extent from the strict purity of God's word' (Calvin, Commentary on 1 Corinthians 3:15). ${ }^{1}$

When it came to biblical exposition, however, Calvin summoned and praised the interpretive work of Chrysostom. In Calvin's estimation, Augustine and Chrysostom excelled at differing tasks. Calvin looked to Augustine for doctrinal support and to Chrysostom for interpretive insights (Zachman 2001: 15n45). As Michael Carl Armour surmises, ‘... Calvin adapted a style as reminiscent of Chrysostom expositionally as it was of Augustine theologically' (Armour 1992: 124). Because of this focus, Calvin exhibited great interest in Chrysostom's homilies. Calvin's access to the Latin Chevallon edition (1536) of Chrysostom is 'considered proven' (Kreijkes 2016b: 347; cf. Kreijkes 2016; Papp 2016: 428). Kreijkes has recently argued that Calvin used the Chevallon edition among others only during his last Genevan period, and that scholars must seek to establish which particular Chrysostomic edition Calvin used for each of his works (Kreijkes 2016). Kreijkes has further argued that Calvin might have also read Chrysostom in Greek (Kreijkes 2016b; contrast Papp 2016: 432). In spite of his respect for the exposition of the Antiochene commentator, Calvin disagreed with various scriptural interpretations found in Chrysostom (Ahn 1999: 230). Calvin could critique specific arguments from Chrysostom as 'excessively weak', and cases of his interpretation as 'poor' (Calvin, Commentary on Colossians $1: 15 ; 2: 16)$. Yet he refused to cast Chrysostom aside through a 'wholesale dismissal' (Armour 1992: 127).

While Calvin looked to Augustine for dogmatic instruction, he looked to Chrysostom for biblical interpretive guidance (Ganoczy \& Scheld 1983: 179; Zachman 2006: 67n4). Calvin's dependence upon Augustine's theological insights readily appears in two works, his Institutes of the Christian Religion and his Bondage and Liberation of the Will. In the latter, Calvin quotes twentyfive of Augustine's works, along with thirty-three works from other authors (Lane 1997: 69, 83). Anthony Lane muses that 'those who read the treatise will be struck by the paucity of reference to other fathers compared to the wealth of material on Augustine' (Lane 1997: 79). Lane explains the lopsid-

1 English translations of Calvin's commentaries come from the Pringle editions (Grand Rapids: Eerdmans). 
ed usage of Augustine based upon availability, compressed time of composition, and especially theological agreement (Lane 1997: 84).

Chrysostom barely appears within the Bondage and Liberation of the Will, and the few instances merely reflect prior employment in the Institutes (Lane 1997: 84, 94). Within the Institutes themselves, Calvin's patristic usage can basically be divided into two 'distinct halves', Augustine and the other fathers (Lane 1997: 88; cf. Lane 1981: 159). According to Johannes van Oort, Calvin's use of Gregory the Great within the Institutes comes in a distant second behind Augustine (van Oort 1997: 694). His employment of Chrysostom comes in third, with about forty-five citations, including references to Pseudo-Chrysostom (van Oort 1997: 684). Thirty-one of the citations relate to Chrysostom's interpretations of the Apostle Paul's Epistle to the Romans (van Oort 1997: 674; cf. the statistics in Lane 1981: 201-205).

Peter Moore maintains that three evidences demonstrate 'Calvin's enthusiasm for Chrysostom' (Moore 2009: 110). First, Calvin composed a preface to a proposed translation of Chrysostom's sermons into French (the focus of this present essay). Second, Calvin conspicuously referenced Chrysostom within his Institutes of the Christian Religion. The Institutes reflect Calvin's expectation that his readers would possess 'some familiarity with the writings of the church fathers, especially Augustine and Chrysostom' (Zachman 2006: 82). Third, Calvin annotated his personal copies of Chrysostom (still available in the Geneva Library) with marginalia notes and underlining, as discussed in the investigation of Alexandre Ganoczy and Klaus Müller (1981). A fourth evidence can be added, as reflected in one of Moore's discursive footnotes: Calvin employed Chrysostom's insights within his own biblical commentaries, and Chrysostom was the most frequently cited father in his New Testament commentaries (Kreijkes-van Esch 2017: 261). According to the index of the Corpus Reformatorum, Calvin's New Testament commentaries refer to Chrysostom 105 times and to Augustine 101 times (Steinmetz 1990: 116). Yet these statistics, which rely upon explicit references, do not reveal the full influence of Chrysostom upon Calvin's commentaries (Steinmetz 2010: 133).

John Walchenbach has examined Chrysostom's influence upon Calvin's Corinthian commentaries in particular (Walchenbach 2010: 47-116). More recently, Jeannette Kreijkes-van Esch has focused upon Chrysostom's and Calvin's exposition of Galatians (Kreijkes 2017). Interestingly, Kreijkes-van Esch concludes that 'Calvin's exegesis does not have much in common with Chrysostom's' (Kreijkes van-Esch 2017: 270). Although perhaps an overstatement, this assertion does signal an underlying issue. In Calvin's commentary, 'the exegesis produces doctrina, but doctrina also forms the frame- 
work for the exegesis' (Kreijkes-van Esch 2017: 271; cf. d'Assonville 2009; Kreijkes 2017). ${ }^{2}$ This dialectical movement reflects Calvin's own hermeneutical and theological emphases, which in turn are reflected in his personal assessment of Chrysostom, as presented below.

\section{Calvin's Preface to Chrysostom's Homilies}

Calvin composed a preface to a proposed edition of the sermons of John Chrysostom (Praefatio in Chrysostomi Homilias). Ian Hazlett has called the preface 'One of the traditional puzzles in Calvin studies' (Hazlett 1991: 129). Hazlett explains, 'The date, circumstances, and precise scope of this project have always been uncertain, chiefly because the only evidence for the plan is a substantial fragment of a prefatory introduction in Calvin's own hand' (Hazlett 1991: 129). The preface is a draft in Latin, and the proposed project of an edition of Chrysostom's sermons never came to publication. Most likely, Calvin intended the edition to be in French (Hazlett 1991: 130). Calvin labeled his proposed translation as 'unconventional (inusitatum)' (Hazlett 1991: 138), and he noted that not all church ministers were sufficiently versed in Greek and Latin (Kreijkes 2016b: 348). Hazlett argues (and reasonably so) that Calvin's intention was to transition the preface itself into French as well. 'What we have', explains Hazlett, 'is a first draft, with its errors, corrections, deletions, interlinear and marginal insertions, sometimes minor, sometimes major, its extensive abbreviations, and so on' (Hazlett 1991: 130-131).

While Walchenbach maintained that Calvin composed the preface in 1559 (Walchenbach 2010: 175), Hazlett built a case for the late 1530s (Hazlett 1991: 132-133). Kreijkes similarly landed upon 1538 (Kreijkes 2016b: 347). Hazlett's chronological placement relied upon paleographic evidence, as well as the watermark on the paper of the draft. Moreover, Calvin's personal copies of a 1536 Paris edition of Chrysostom's works contain the Reformer's marginal notes and reader's highlights. 'It would seem', comments Hazlett, 'that Calvin was using Chrysostom as a means of learning how to preach sermons with practical relevance' (Hazlett 1991: 133). Irena Backus sides with those who date the preface 'provisionally' at 1540, 'although that date can only be considered as approximate' (Backus 2000: 254).

The extant draft of Calvin's preface has been translated into English on two occasions. In a 1965 entry within The Hartford Quarterly, John H. McIndoe presented the first English translation of the Latin text (McIndoe 1965). In 1991, Hazlett re-translated Calvin's preface into English. Hazlett spelled out his rationale for the necessity of this re-translation. First, he work also informed his personal interpretation of the Galatian texts. 
could only trace down one copy of McIndoe's work, in the Trinity College Collection of the Glasgow University Library. ${ }^{3}$ Second, he desired to make McIndoe's translation 'more readily available on this side of the Atlantic' (Hazlett 1991: 131). Third, Hazlett reasoned that 'dubious and occasionally inexplicable renderings' in McIndoe's rendition warranted 'a fresh translation' (Hazlett 1991: 131). Fourth, McIndoe only worked with the Latin text found in the thirty-sixth volume of the Corpus Reformatorum (1870), while Hazlett took into account variant readings found in various transcripts. Fifth, McIndoe's work was 'completely devoid of an introduction and helpful footnotes' (Hazlett 1991: 131). By contrast, Hazlett purposed to provide 'generous annotation' (Hazlett 1991: 131).

In a key paragraph within his introduction, Hazlet delineated the importance of Calvin's preface to Chrysostom's sermons: 'Whatever the problems surrounding this Calvin fragment, its contents are a transparent testimony of the relationship between Christian humanism and the Reformation; between the rediscovery of the sources of Christian (and Jewish) Antiquity by reform-minded Catholics, which accompanied the Renaissance, and the theological and religious revolution initiated by Luther; and between patristic tradition and Scripture in the mind of a Reformer. Calvin's document is a miniature, embodying one of the most distinctive and potent amalgams of these forces' (Hazlett 1991: 129-130).

In sum, Hazlett wished to illuminate the socio-cultural forces of Christian humanism, the Renaissance, and the Reformation as they are reflected in Calvin's preface.

The purpose of this present article is to make a more foundational argument: Calvin's evaluations of Chrysostom and other patristic authors, as found in the preface, provide a window into his own personal interpretive concerns, homiletical aims, and dogmatic emphases. In his draft preface to Chrysostom's commentaries, Calvin constructs three major strands of argumentation (cf. Walchenbach 2010: 176-180).

First, Calvin justifies the necessity of publishing an edition of Chrysostom's sermons in the vernacular of the laity. Second, Calvin explains why Chrysostom's sermons outshine those of all other patristic preachers. Third, Calvin defends why Chrysostom is worth reading even though Calvin disagrees with important facets of his theology.

These three strands of evaluation reflect Calvin's own hermeneutical, pastoral, and theological values. gion Database. 


\section{The Necessity of Reaching the General Public}

First, Calvin justifies the necessity of publishing an edition of Chrysostom's sermons in the vernacular of the laity. Calvin clearly wished 'to make Chrysostom's literature accessible to the wider sphere of society' (Awad 2010: 422). Yet he also surmised that his project would face opposition. He mused, 'For I am aware of what nearly always happens in the case of innovation, that there will be no lack of people who will not only condemn this work of mine as unnecessary, but also are of the opinion that it ought to be rejected out of hand as being of no particular benefit to the Church' (Hazlett 1991: 138). ${ }^{4}$

Hazlett reasons that Calvin may have been influenced by the "popular rejection' of his Genevan Confession of Faith in 1537-1538. 'The person on the street was simply unmoved by it' (Hazlett 1991: 135-136). The views of radical Reformers may also have been lurking in the shadows. Thomas Müntzer decried those who relied upon the church fathers for biblical interpretation, calling such individuals 'mischievous scripture thieves', 'spiteful biblical scholars', and 'modern Pharisees' (see Awad 2010: 424).

In response, Calvin argued that secondary aids, such as Chrysostom's sermons, could assist with the study and interpretation of Scripture. While Calvin upheld the supremacy of Scripture, he also defended 'authentic and authoritative' secondary literature (Awad 201: 423). Calvin reasoned that the reader of Scripture benefits from reliable guides (Awad 2010: 425). The Holy Spirit's work cannot be boundaried or controlled, and he may freely choose to employ secondary aids to elucidate the meaning of scripture texts (Hazlett 1991: 141). Therefore, 'there is no reason', argues Calvin's preface, 'either to neglect [secondary means] as superfluous, or even to care less about them as if irrelevant' (Hazlett 1991: 141). In this manner, Calvin chooses a decidedly pneumatological framework to defend the Spirit's use of secondary means. As Najeeb George Awad notes, 'From a theological point of view, Calvin seeks through translating Chrysostom's homilies to show the Christian public that the Holy Spirit does not work only through the canonical texts' (Awad 2010: 426).

According to Randall Zachman, Calvin's general tactic was to target pastors as the primary audience for his Institutes and biblical commentaries, and to target ordinary Christians as the primary audience for his catechism and homilies (Zachman 2001: 6; Zachman 2006: 60). Zachman acknowledges that 'a watertight distinction' cannot be absolutely maintained between these audiences (Zachman 2001: 6n20). The 'primary audience' for the Institutes 
was future pastors and teachers, but the translation of the work into French reflects a secondary interest in 'ordinary Christians' (Zachman 2001: 12, n. 38). Calvin also contended that not all clerics were competent in the classical languages of Greek and Latin. Calvin pointed to the blessing accrued by making the Gospel available to the public. If the Word of God is the instrument of God's saving work, then it should not be 'hidden in the libraries of a select few, inaccessible to the general public' (Hazlett 1991: 140).

Calvin reasoned that Chrysostom himself was an exemplar of reaching the general public (universum populum) (see Walchenbach 2010: 21). In this sense, Calvin allied himself with Chrysostom in a 'common cause' (Walchenbach 2010: 22; cf. Hazlett 1991: 142-143). According to Calvin, Chrysostom's sermons target 'a wide public'-he 'plainly adjusts both [his] approach and language as if he had the instruction of the common people in mind' (Hazlett 1991: 142). In Calvin's estimation, Chrysostom exemplified 'a down-to-earth form of preaching which is reflective of God's infinite love and intimate presence in human existence' (Awad 2010: 426). Calvin desired to bring Chrysostom's homilies to a contemporary audience. 'All I have had in mind with this is to facilitate the reading of Holy Scripture for those who are humble and uneducated' (Hazlett 1991: 142). Calvin found his motto, 'Scripture for the people', echoed in the labor of the goldenmouthed preacher (Ganoczy \& Scheld 1983: 118; Walchenbach 2010: 19).

Calvin's response in this first strand of argumentation reflects his own framework of pastoral values. Calvin valued bringing the Scriptures and helpful aids into the hands of the common populace (Backus 2000: 256). This priority is already evident in his Latin and French prefaces to Olivetan's French translation of the Bible (Zachman 2001: 2). At that early stage, he already brought Augustine and Chrysostom into the discussion: 'Chrysostom and Augustine-when do they not urge the common people to this study-how frequently they insist that what they hear in church they should apply in homes? Why is it that Chrysostom contends that the reading of Holy Scripture is more necessary for common people than monks?' (quoted in Zachman 2001: 2-3). Calvin not only wanted the Scriptures in the hands of the laity, he also desired to provide godly interpreters to guide them in Bible reading (Zachman 2001: 3). 'In sum', reasons Zachman, 'Calvin envisioned a church in which every Christian would read Scripture for her/himself, under the guidance of their pastors, who themselves would be guided by the teachers of the church catholic' (Zachman 2001: 10).

\section{The Preference for Chrysostom's Homilies}

Second, Calvin explains why Chrysostom's sermons surpass those of all other patristic preachers. As Hazlett notes, 'The interpreter and presenter of the Word par excellence in Antiquity is John Chrysostom, whose Homilies 
and exegetical skill excel those of any other Church Father' (Hazlett 1991: 134). Not all Reformers shared Calvin's appreciation for Chrysostom. Luther criticized Chrysostom's work as a 'chaotic heap of words without substance... argumentative and garrulous' (quoted in Hazlett 1991: 137). Luther also castigated the loquacious oratory and verbosity of Chrysostom (Hazlett 1991: 137). Of course, Calvin's hermeneutical presuppositions differed from those of Luther (Armour 1992).

According to Calvin, praiseworthy biblical interpretation should also be 'profitable, useful, and edifying for the Church' (Hazlett 1991: 136). Calvin evaluated the patristic authors with this framework in place. Origen obscured 'the plain meaning of Scripture with constant allegories' (Hazlett 1991: 144). Basil and Gregory obscured the scripture's meaning through grandiloquence, having "more of an aptitude for oratory than for literary exposition' (Hazlett 1991: 144). Hilary lacked lucidity, 'the most important faculty of an interpreter' (Hazlett 1991: 145). Jerome was 'almost completely bogged down in allegories', and he comes across as 'a man not sufficiently experienced in church affairs' (Hazlett 1991: 145). Ambrose's works, though 'very laconic', come 'closer to the plain sense of Scripture' (Hazlett 1991: 145). Even Augustine was 'far too ingenious', resulting in him being 'less sound and reliable' (Hazlett 1991: 145).

Calvin differentiates the work of Chrysostom, who manifested simplicity and lucidity. 'The chief merit of our Chrysostom is this: he took great pains everywhere not to deviate in the slightest from the genuine plain meaning of Scripture [germana scripturae sinceritate], and not to indulge in any license of twisting the straight forward sense of the words [ac nullam sibi licentiam sumere in simplici verborum sensu contorquendo]' (Hazlett 1991: 146). Calvin esteemed the simplicitas of Chrysostom's interpretive approach (Kreijkes-van Esch 2017: 262). Similar to the Praefatio, Calvin's other writings identify the 'natural (germanus)' and 'simple (simplex)' meaning of scripture with the 'literal sense (sensus literalis)' (Kreijkes-van Esch 2017: 264-265; cf. Burnett 2004).

Calvin defends Chrysostom as a thorough expositor and a practical preacher (Awad 2010: 426). In Calvin's view, Chrysostom 'was without peer among the ancients as an interpreter of the Bible' (Moore 2009: 111). 'Of all the Fathers, he awarded to Chrysostom the first place in the exposition of Scripture' (van Oort 1997: 691). According to Calvin, Cyril of Alexandria is 'someone who among the Greeks can be rated second to Chrysostom', although he cannot rival him (Hazlett 1991: 144). Therefore, Chrysostom stands at the 'apex' of Calvin's estimation of the Greek fathers (Backus 2000: 258).

Above all, Calvin's esteem for Chrysostom centered upon his 'simple, literal-historical approach to the text' (Bouwsma 1988: 119). This assessment 
reveals Calvin's own framework of hermeneutical values. Calvin maintained that he and Chrysostom shared a 'common concern' or 'common cause [causam communem]' (Hazlett 1991: 142). ${ }^{5}$ Two of Calvin's crucial tenets of exegesis were the principles of perspicua brevitas and sensus genuinus (Kraus 1968: 334, 336). As Zachman explains, '...Calvin sets forth the true, simple, and genuine meaning of Scripture, by showing how such meaning flows smoothly and naturally from the context, thereby revealing the mind of the author of Scripture with lucid brevity' (Zachman 2001: 11). In his dedicatory letter to Simon Grynaeus, Calvin felt that 'lucid brevity constituted the particular virtue of an interpreter' (quoted in Zachman 2001: 11n35). Chrysostom manifested Calvin's own hermeneutical ideal of brevitas et facilitas (Ahn 1999: 238; Walchenbach 2010: 165).

\section{The Acknowledgement of Theological Differences}

Third, Calvin defends why Chrysostom is worth reading even though he disagreed with important facets of his theology. Fascinatingly, the original manuscript of Calvin's preface reveals that this third discussion was an 'appended insertion' (Hazlett 1991: 134). Calvin pinpointed areas of disagreement residing within the doctrines of election, predestination, free will, human cooperation, grace, and merit. In Calvin's view, Chrysostom 'makes too much concession to human capacity and virtue' (Hazlett 1991: 134). In his Institutes, Calvin had commented that 'All ecclesiastical writers have recognized both that the soundness of reason in man is gravely wounded through sin, and that the will has been very much enslaved by evil desires. Despite this, many of them have come far too close to the philosophers' (Calvin, Institutes II.2.4). ${ }^{6}$ According to Calvin's preface to Chrysostom's sermons, the philosophers had little room for 'the blindness of human nature, the perversity of the heart, the impotence of the mind, and the corruption of the entire character' (Hazlett 1991: 148).

Calvin's inter alia notes within the Institutes remind readers that Chrysostom had to contend with the contemporary philosophical emphases upon free will and also with moral laxity within the Church (Institutes II.5.2-3; van Oort 1997: 693). But in matters of grace, free will, election, and predestination, Calvin found a more trustworthy ally in Augustine (Todd 1964: 191; Ganoczy \& Sheld 1983: 179). He contended, 'Further, even though the Greeks above the rest-and Chrysostom especially among them-extol the ability of the human will, yet all the ancients, save Augustine, so differ, wa-

$5 \quad$ Some textual witnesses have causam coniunctam. See Hazlett 1991: 142.

6 English translations of Calvin's Institutes come from the McNeill edition (Philadelphia: Westminster, 1960). 
ver, or speak confusedly on this subject, that almost nothing certain can be derived from their writings' (Institutes II.2.4).

György Papp maintains that Calvin's critique of Chrysostom is "not only rather sharp' but also 'very warped' (Papp 2016: 431). Within five chapters of the Institutes that focus upon the corruption of free will within humanity, Calvin includes eleven quotations attributed to Chrysostom-in a critical manner in nearly every case (Papp 2016: 424-425). In two instances, Calvin attributed spurious quotations to Chrysostom (cf. Steinmetz 1990: 113-114). Papp believes that Calvin was aware of doubts concerning the Homilia prima in adventu in particular but chose to overlook them, because 'he did not want to ascribe a thought he accepted as a good one to an unknown Arian author' (Papp 2016: 431). Of the remaining nine genuinely Chrysostomic quotations, only one could be considered a 'positive' estimation (Papp 2016: 431). Papp contends that a bad Latin translation contributed to Calvin's critical evaluation of Chrysostom in one of the eight 'negative' cases (Papp 2016: 429).

On occasion, Calvin even labeled Chrysostom's interpretations as 'absurd' and 'very constrained' (see van Oort 1997: 692). Yet Calvin refused to dismiss Chrysostom in a wholesale manner (Hazlett 1991: 137). He esteemed Chrysostom as a 'trusty minister of Christ' who 'did deviate somewhat from the right way, although he had the best of intentions' (Hazlett 1991: 149). Calvin tries to explain away theological differences based upon the extenuating 'circumstances of the times' and contextual pressures that Chrysostom faced (Hazlett 1991: 134, 136). In Walchenbach's judgment, Calvin's magnanimity 'stretches every nerve to exonerate Chrysostom's theological deficiencies' (Walchenbach 2010: 26).

In his Treatise on Scandals, Calvin claimed that most of the fathers caved into 'the common judgment of the flesh', suffering from 'desire to please the wise of the world, or at least from fear of annoying them' (quoted in Todd 1964: 192). Calvin's treatise added, 'Certainly Origen, Tertullian, Basil, Chrysostom and others like them would never have spoken as they do, if they had followed what judgment God had given them. ... These good persons seek a means more in conformity with human understanding: that is to concede I know not what to free will, and allow some natural virtue to man; but meanwhile the purity of the doctrine is profaned' (quoted in Todd 1964: 192). On the other hand, Calvin declared of the fathers, 'Yet I dare affirm this: however excessive they sometimes are in extolling free will, they have this end in view-to teach man utterly to forsake confidence in his own virtue and to hold that all his strength rests in God alone' (Institutes II.2.9).

Calvin argues that even though Chrysostom falls short in his theological stances, his sermons remain instructive regarding the life, worship, and discipline of the early church (Hazlett 1991: 150). Chrysostom thus provides 
an example of a 'model from the early church [normam a veteri ecclesia]' (Hazlett 1991: 150). Awad concludes, Chrysostom's 'exegetical method and pastoral concern override... his criticism of the theological content of Chrysostom's commentaries' (Awad 2010: 424). Nevertheless, Calvin explicitly warned that readers should exercise caution, lest they 'be diverted from the plain truth' by Chrysostom's 'authority' (Hazlett 1991: 150).

Calvin acknowledged that Chrysostom differed in theological emphases, but he claimed him as an ally in method of biblical exegesis (Awad 2010: 427). One senses some tension here. Calvin believes that doctrine should arise from the plain meaning of scripture, he concedes that Chrysostom excelled at such biblical interpretation, yet he disagreed with Chrysostom's theological conclusions. Todd reflects, 'On the one hand, Calvin states that in exegetical matters Augustine was too allegorical in his treatment of the text and excessively Platonic in some of his interpretations and that he preferred Chrysostom because his exegesis was more 'natural' and literal (in the grammatico-historical sense). On the other hand, Calvin states that Augustine's over-all interpretation of the economy and doctrine of Scripture is superior to that of Chrysostom' (Todd 1964: 179).

Chrysostom comes off as the 'perfect biblical commentator for the common man, but not to be followed in his teaching on free will' (Backus 2009: 136). Calvin does not elucidate how Chrysostom's 'superior exegetical method could result in inferior doctrine' (Todd 1964: 179). But such tensions are not uncommon in Calvin. As Armour noted, Calvin could 'compliment Augustine and simultaneously slap his wrist for improper exegesis' (Armour 1992: 132). On one occasion, Calvin praised Augustine's explanation of a text as being stated 'piously and judiciously' yet having 'nothing to do with the present passage' (Calvin, Commentary on John 1:16). On another occasion, Calvin declared, 'Augustine is quite delighted with his own acuteness, which throws no light on the subject' (Calvin, Commentary on Ephesians 3:18).

Hazlett argues that Calvin's approach is dressed in 'Erasmian, humanist clothes' (Hazlett 1991: 135; cf. Backus 2000: 257). Like Erasmus, Calvin’s preface supports a return to the ethics of 'original Christianity' (Hazlett 1991: 135). Hazlett also maintains that Calvin's defense of Chrysostom reflects 'the Catholic Calvin', both his ecclesial concerns and his sense of the communio sanctorum (Hazlett 1991: 136; cf. Neuser \& Armstrong 1997).

\section{Conclusion}

When it came to patristic sources, Calvin took 'an independent course' (Armour 1992: 135). 'Calvin's respect for the fathers was great, but not unqualified' (Lane 1981: 167). He treated the fathers as 'partners in conversation' but not as final authorities (Steinmetz 1990:117). He respected and 
praised the fathers, yet he also challenged and sometimes even dismissed them (Armour 1992: 135). He recognized that the fathers sometimes contradicted themselves (Lane 1981: 167-168). Calvin's use of the fathers is open to the charge of selectivity (Lane 1981: 189; Backus 2009). Because of this independent and selective approach, his evaluations tend to teach us about the personal values embedded with his own evaluative framework. In particular, Calvin's assessment of John Chrysostom reveals Calvin's own hermeneutical, pastoral, and theological values.

\section{Bibliography}

Ahn MJ (1999) Calvin's Hermeneutic and the Development of His Method. Hervormde Teologiese Studies 55(1): 228-239.

Armour MC (1992) Calvin's Hermeneutic and the History of Christian Exegesis. Ph.D. dissertation. University of California, Los Angeles.

Awad NG (2010) The Influence of John Chrysostom's Hermeneutics on John Calvin's Exegetical Approach to Paul's Epistle to the Romans. Scottish Journal of Theology 63(4): 414-436.

Backus I (2000) Calvin and the Greek Fathers. In Bast RJ and Gow AC (eds) Continuity and Change: The Harvest of Late Medieval and Reformation History. Leiden: Brill, pp. 253-276.

Backus I (2009) Calvin and the Church Fathers. In Selderhuis HJ (ed) The Calvin Handbook. Grand Rapids: Eerdmans: pp. 125-136.

Bouwsma WJ (1988) John Calvin: A Sixteenth-Century Portrait. Oxford: Oxford University Press.

Burnett R (2004) John Calvin and the Sensus Literalis. Scottish Journal of The$\operatorname{ology} 57(1): 1-3$.

Büsser F (1984) Die Rolle der Kirchenväter in Calvins Exegetica. In Neuser WH (ed) Calvinus ecclesiae Genevensis custos: Die Referate des Internationalen Kongresses für Calvinforschung vom 6. bis 9. September 1982 in Genf. Frankfurt am Main: Peter Lang, pp. 163-164.

Calvin J (1863) Praefatio in Chrysostomi Homilias. In Baum G, Cunitz E, and Reuss E (eds) Corpus Reformatorum: Ioannis Calvini Opera quae supersunt omnia, vol. 37. Braunschweig: Schwetschke, cols. 831-838.

d'Assonville VE (2009) Exegesis and Doctrina. In Selderhuis HJ (ed) The Calvin Handbook. Grand Rapids: Eerdmans: pp. 378-384.

Ganoczy A and Müller K (1981) Calvins handschriftliche Annotationen zu Chrysostomus: Ein Beitrag Hermeneutik Calvins. Wiesbaden: Steiner.

Ganoczy A and Scheld S (1983) Die Hermeneutik Calvins: Geistesgeschichtliche Voraussetzungen und Grundzüge. Wiesbaden: Steiner. 
Hartog P (2018) John Chrysostom: Golden-Mouthed Preacher. In Forrest BK, King KL, Curtis B, and Milioni D (eds) A Legacy of Preaching, vol. 1: Apostles to Revivalists. Grand Rapids: Zondervan, pp. 126-145.

Hazlett IP (1991): Calvin's Latin Preface to His Proposed French Edition of Chrysostom's Homilies: Translation and Commentary. In Kirk J (ed) Humanism and Reform: The Church in Europe, England and Scotland, 14001643: Essays in Honour of James K. Cameron. Studies in Church History Subsidia 8. Oxford: Basil Blackwell, pp. 129-150.

Johanson JW (1982) The Exegetical Technique of John Chrysostom and His Influence upon Calvin. M.Phil. thesis. Waterloo, ON: University of Waterloo.

Kraus H-J (1968) Calvins exegetische Prinzipien. Zeitschrift für Kirchengeschichte 79(3): 329-341.

Kreijkes J (2016) Calvin's Use of the Chevallon Edition of Chrysostom's Opera Omnia: The Relationship between the Marked Sections and Calvin's Writings. Church History and Religious Culture 96(3): 237-265.

Kreijkes J (2016b) The Praefatio in Chrysostomi Homilias as an Indication that Calvin Read Chrysostom in Greek. In Selderhuis HJ and Huijgen A (eds) Calvinus pastor ecclesiae: Papers of the Eleventh International Congress on Calvin Research. Reformed Historical Theology 39. Göttingen: Vandenhoeck \& Ruprecht, pp. 347-354.

Kreijkes J (2017) The Impact of Theological Concepts on Calvin's Reception of Chrysostom's Exegesis of Galatians 4:21-6. Studia Patristica 96: 5763.

Kreijkes-van Esch J (2017) Sola Scriptura and Calvin's Appeal to Chrysostom's Exegesis. In Burger H, Huijgen A and Peels E (eds) Sola Scriptura: Biblical and Theological Perspectives on Scripture, Authority, and Hermeneutics. Studies in Reformed Theology 32. Leiden: Brill, pp. 260-275.

Lane ANS (1997) Calvin and the Fathers in Bondage and Liberation of the Will. In Neuser WH and Armstrong BG (eds) Calvinus sincerioris religionis vindex: Calvin as Protector of the Purer Religion. Sixteenth Century Essays and Studies 36. Kirksville, MO: Sixteenth Century Journal Publishers.

Lane ANS (1981) Calvin's Use of the Fathers and the Medievals. Calvin Theological Journal 16 (1981): 149-205.

Lane ANS (1999) John Calvin: Student of the Church Fathers. Edinburgh: T\&T Clark.

McIndoe JH (1965) John Calvin: Preface to the Homilies of Chrysostom. Hartford Quarterly 5(2): 19-26.

Moore P (2009) Gold without Dross: Assessing the Debt of John Calvin to the Preaching of John Chrysostom. Reformed Theological Review 68(2): 109-129. 
Moore P (2011) Plain Talk with a Gilt Edge: An Exploration of the Relation between 'Plain' Biblical Exposition and Persuasion in Chrysostom and Calvin. Westminster Theological Journal 73(1): 157-172.

Papp G. (2016) Aspects of Calvin's Use of Chrysostom-Quotations Concerning the Free Will: How did Calvin Quote Chrysostom in the Chapters Concerning the 'Free Will' of his Institutes? In Selderhuis HJ and Huijgen A (eds) Calvinus pastor ecclesiae: Papers of the Eleventh International Congress on Calvin Research. Reformed Historical Theology 39. Göttingen: Vandenhoeck \& Ruprecht, pp. 423-434.

Pretila N (2006) The Influence of John Chrysostom and Cyril of Alexandria on Calvin's Institutes. Th.M. thesis. Dallas Theological Seminary.

Smits L (1958) Saint Augustine dans l'oeuvre de Jean Calvin, 2 vols. Assen: Van Gorcum.

Steinmetz DC (1990) Calvin and the Patristic Exegesis of Paul. In Steinmetz C (ed) The Bible in the Sixteenth Century. Durham: Duke University Press, pp. 100-118, 231-235.

Steinmetz DC (2010) Calvin and Patristic Exegesis. In Calvin in Context, second edition. Oxford: Oxford University Press, pp. 120-138.

Todd WN (1964) The Function of the Patristic Writings in the Thought of John Calvin. Th.D. dissertation. Union Theological Seminary.

Torrance TF (1988) The Hermeneutics of John Calvin. Edinburgh: Scottish Academic Press.

van Oort J (1997) John Calvin and the Church Fathers. In Backus I (ed) The Reception of the Church Fathers in the West: From the Carolingians to the Maurists, vol. 2. Leiden: Brill, pp. 661-700.

Walchenbach J (2010) John Calvin as Biblical Commentator: An Investigation into Calvin's Use of John Chrysostom as an Exegetical Tutor. Eugene, OR: Wipf \& Stock.

Warfield BB (1956) Calvin and Augustine. Philadelphia: Presbyterian and Reformed.

Wendel F (2002) Calvin: Origins and Development of His Religious Thought. Grand Rapids: Baker.

Zachman RC (2001) 'Do You Understand What You Are Reading?' Calvin's Guidance for the Reading of Scripture. Scottish Journal of Theology 54(1): $1-20$.

Zachman RG (2006) John Calvin as Teacher, Pastor, and Theologian: The Shape of His Writings and Thought. Grand Rapids: Baker Academic.

Zillenbiller A (1993) Die Einheit der katholischen Kirche: Calvins Cyprianrezeption in seinen ekklesiologischen Schriften. Mainz: von Zabern. 